Protocol

\title{
Northern Blots for Small RNAs and MicroRNAs
}

\author{
Donald C. Rio
}

This protocol describes the detection of small RNAs ( $\sim 10-200$ nucleotides) by blot hybridization. The RNA samples, denatured in formamide, are separated by denaturing polyacrylamide gel electrophoresis. Because high-percentage polyacrylamide gels are required to separate RNAs in this size range, it is necessary to perform electrophoretic transfer to positively charged nylon membranes. After transfer, the immobilized RNAs are subjected to hybridization with a ${ }^{32} \mathrm{P}$-radiolabeled DNA or RNA probe and detected by phosphorimaging or autoradiography. This procedure is commonly used to detect small, U-rich spliceosomal small nuclear RNAs (snRNAs) and miRNAs. It should be possible also to detect most miRNAs using high-percentage (e.g., 15\%) urea-polyacrylamide gel electrophoresis.

MATERIALS

It is essential that you consult the appropriate Material Safety Data Sheets and your institution's Environmental Health and Safety Office for proper handling of equipment and hazardous materials used in this protocol.

RECIPES: Please see the end of this protocol for recipes indicated by $<R>$. Additional recipes can be found online at http://cshprotocols.cshlp.org/site/recipes.

\section{Reagents}

Electrophoretic transfer buffer $(20 \times)<\mathrm{R}>$

Dilute the $20 \times$ stock to $1 \times$ in $\mathrm{H}_{2} \mathrm{O}$ and precool to $4^{\circ} \mathrm{C}$ before use. Alternatively, use TBE electrophoresis buffer $(10 x)<R>$, diluted to $0.5 \times$. See Steps 4 and 5.

Formamide gel-loading buffer $<\mathrm{R}>$

Polyacrylamide-urea gel $(10 \%-15 \%)$ and electrophoresis reagents

Prehybridization/hybridization mix for northerns $<\mathrm{R}>$

Probe DNA or RNA, labeled at $2 \times 10^{8}$ to $5 \times 10^{8} \mathrm{cpm} / \mu \mathrm{g}$

The probe is typically a DNA oligonucleotide, end-labeled by kinasing, or an antisense in vitro RNA transcript, labeled internally.

RNA marker ladder (10-150 nucleotides; e.g., U.S. Biochemicals Low Molecular Weight Marker or Ambion Decade Marker System)

The marker can be radiolabeled by kinasing and run in parallel with the unlabeled RNA samples in Step 2. It also serves as a control for electrophoretic transfer from the gel.

RNA samples (each $\sim 10-15 \mu \mathrm{g}$ of total RNA)

SSC for northerns $(20 \times)<\mathrm{R}>$

SDS $(10 \%)$

Adapted from RNA: A Laboratory Manual by Donald C. Rio, Manuel Ares Jr, Gregory J. Hannon, and Timothy W. Nilsen. CSHL Press, Cold Spring Harbor, NY, USA, 2011.

(C) 2014 Cold Spring Harbor Laboratory Press

Cite this protocol as Cold Spring Harb Protoc; doi:10.1101/pdb.prot080838 
D.C. Rio

Equipment

Autoradiography or phosphorimaging equipment

Ballpoint ink pen for marking the filter

Containers for hybridization (polyethylene heat-seal bags or cylindrical glass hybridization bottles) If heat-seal bags are used, a heat sealer (e.g., National Instruments, Model 310) will be required.

Electroblot transfer tank and power supply (e.g., Bio-Rad Trans-Blot cell with wire electrodes and PowerPac HC Power Supply)

Nylon transfer membrane (positively charged; e.g., GE Healthcare, Hybond-N+)

The membrane should be cut to the same size as the gel.

Oven with shaker or hybridization oven with a rotating rack for glass hybridization bottles, set at $42^{\circ} \mathrm{C}$

Plastic wrap

Polyacrylamide gel electrophoresis system and power supply

The gel is typically $\sim 18 \times 18-\mathrm{cm}, 1.5 \mathrm{~mm}$ thick, set with a 20-well comb. For details, see Polyacrylamide Gel Electrophoresis of RNA (Rio et al. 2010).

Stratalinker (Stratagene) with 254-nm bulbs

Alternatively, use a 254-nm UV transilluminator or vacuum oven set at $80^{\circ} \mathrm{C}$ (see Step 7).

Water bath or temperature block $\left(90^{\circ} \mathrm{C}\right)$

Whatman $3 \mathrm{MM}$ chromatography paper (four sheets must be the same size as the gel; see Steps 3 and 4)

$\stackrel{\infty}{\infty}$ METHOD

Denaturing Polyacrylamide-Urea Gel and Electrophoretic Transfer

1. Resuspend each RNA sample ( $\sim 10-15 \mu$ g of total RNA) in $8-12 \mu \mathrm{L}$ of formamide gel-loading buffer. Heat the samples for $2 \mathrm{~min}$ at $90^{\circ} \mathrm{C}$.

2. Load the samples and the RNA marker ladder onto a high percentage (10\%-15\%) denaturing polyacrylamide-urea gel. Run the gel between 15 and $20 \mathrm{~W}$ on constant power, usually for 3-4 h, or until the bromophenol blue (in the formamide gel-loading buffer) is near the bottom of the gel. For details, see Polyacrylamide Gel Electrophoresis of RNA (Rio et al. 2010).

3. Remove the gel from the tank and separate the plates. Wet two sheets of Whatman 3MM paper with $20 \times$ SSC and place them on top of the gel.

4. Set up the electroblot transfer:

i. Soak a sponge from the electroblot apparatus in electrophoretic transfer buffer until wet.

ii. Transfer the gel with the paper onto the sponge, such that the paper is on top of the sponge.

iii. Float the nylon transfer membrane in $\mathrm{H}_{2} \mathrm{O}$ until wet, then immerse it in $20 \times$ SSC.

iv. Place the nylon membrane on top of the gel and remove any bubbles.

v. Wet two more sheets of Whatman 3MM paper with $20 \times$ SSC, and place them on top of the membrane.

vi. Add the second sponge on top of the Whatman paper sheets and clamp the cassette closed.

The layers of the sandwich are as follows, starting with the negative (-) pole: sponge, two sheets of Whatman 3MM paper, gel, nylon membrane, two sheets of Whatman 3MM paper, sponge. The RNA will migrate to the positive $(+)$ pole.

5. Place the assembled gel cassette into the electroblot chamber and fill the chamber with $1 \times$ electrophoretic transfer buffer, precooled to $4^{\circ} \mathrm{C}$. Carry out the transfer at $250 \mathrm{~mA}$ for $2 \mathrm{~h}$ at $4^{\circ} \mathrm{C}$ and then at $350 \mathrm{~mA}$ for a further $2 \mathrm{~h}$ at $4^{\circ} \mathrm{C}$. 
Cross-Linking, Prehybridization, and Hybridization

6. Prepare the membrane for cross-linking:

i. Disassemble the apparatus. Remove and save the nylon membrane.

ii. Carefully remove any gel fragments from the membrane and mark the orientation of the membrane with a ballpoint ink pen.

iii. Wrap the membrane in plastic wrap and place it on a sheet of Whatman 3MM paper.

7. To cross-link the RNA to the nylon transfer membrane, place the membrane in a Stratalinker with the RNA surface facing up. Expose it to short-wave UV light $(254 \mathrm{~nm}$; the $1200 \mathrm{~mJ}$ autocross-linking setting in a Stratalinker) for $1 \mathrm{~min}$.

Alternatively, use a 254-nm UV transilluminator, exposing the membrane with the RNA surface facing down against the glass surface; or bake the membrane in a vacuum oven for $1 \mathrm{~h}$ at $80^{\circ} \mathrm{C}$.

For microRNAs (miRNAs; RNAs <50 nucleotides), covalent chemical cross-linking (Pall and Hamilton 2008) may be used to fix the small RNAs to the nylon membrane.

8. Place the membrane in a heat-seal bag or cylindrical glass hybridization bottle and cover with prehybridization/hybridization mix, using $10 \mathrm{~mL}$ for a heat-seal bag or $\sim 3-5 \mathrm{~mL}$ for a small hybridization tube. Prehybridize the membrane with shaking or rotation for at least $2 \mathrm{~h}$ at $42^{\circ} \mathrm{C}$.

9. Replace the buffer with an appropriate volume of fresh prehybridization/hybridization mix containing radiolabeled probe at $10^{6} \mathrm{cpm} / \mathrm{mL}$, and hybridize overnight at $42^{\circ} \mathrm{C}$.

Washing and Detection

10. Remove and safely dispose of the radioactive hybridization buffer.

11. Prepare three wash solutions: $2 \times$ SSC $/ 1 \%$ SDS, $1 \times$ SSC $/ 1 \%$ SDS, and $0.1 \times$ SSC.

12. Perform the following series of 15 -min washes on the membrane, each at $42^{\circ} \mathrm{C}$ with agitation:

i. $2 \times \mathrm{SSC} / 0.1 \% \mathrm{SDS}$

ii. $1 \times \mathrm{SSC} / 0.1 \%$ SDS

iii. $0.1 \times$ SSC

13. Air-dry the membrane, cover it with plastic wrap and expose it to a phosphor screen for phosphorimaging or to X-ray film for autoradiography.

Exposure for several hours to overnight may be necessary.

14. Image on a phosphorimager or develop the X-ray film.

See Troubleshooting.

Problem (Step 14): A high background is observed on the membrane.

Solutions: High background may be reduced by one of the following approaches.

1. Try prehybridizing for a longer period of time (Step 8).

2. When preparing the prehybridization/hybridization mix, include tRNA and/or poly(A) at a concentration of $200 \mu \mathrm{g} / \mathrm{mL}$.

3. Polyacrylamide sticking to the membrane can cause high background by retaining the excess probe or unincorporated label. After transfer and while the membrane is still wet (Step 6.ii), "wash" the side of the membrane in contact with the gel in $1 \times$ electrophoretic transfer buffer using gloved fingers. 
D.C. Rio

Problem (Step 14): The bands are faint or absent.

Solution: For the detection of miRNAs and other 20- to 30-nucleotide RNAs, it may be useful to try using low-stringency hybridization conditions (e.g., a low-stringency Church and Gilbert hybridization buffer containing $10 \mathrm{mg} / \mathrm{mL}$ BSA, $0.5 \mathrm{~m}$ sodium phosphate [pH 7.2], $1 \mathrm{~mm}$ EDTA, and 7\% SDS) and to omit the high-stringency wash in Step 12.iii.

\section{RELATED INFORMATION}

One disadvantage of northern blotting is that it is relatively insensitive. For greater detection sensitivity, the splinted RNA ligation method is preferred (see Splinted Ligation Method to Detect Small RNAs [Nilsen 2013]).

\section{RECIPES}

Denhardt's Solution for Northerns (100x)

Reagent Quantity (for 1 L) Final concentration (100×)

Polyvinylpyrrolidone

Bovine serum albumin

(Type V)

Ficoll 400

EDTA (250 mm, pH 8.0)

$\mathrm{H}_{2} \mathrm{O}$

Store a working stock at $4^{\circ} \mathrm{C}$. For long-term storage $(>1 \mathrm{yr})$, store at $-20^{\circ} \mathrm{C}$.

Electrophoretic Transfer Buffer (20×)

Reagent

Quantity (for 1 L)

Final concentration $(20 \times)$

Trisodium citrate

Sodium phosphate, dibasic

$\left(\mathrm{Na}_{2} \mathrm{HPO}_{4}\right)$

$\mathrm{H}_{2} \mathrm{O}$

$35.29 \mathrm{~g}$

$22.71 \mathrm{~g}$

$120 \mathrm{~mm}$

$160 \mathrm{~mm}$

to $1 \mathrm{~L}$

Adjust the $\mathrm{pH}$ to 8.3 , autoclave, and store for up to $1-2 \mathrm{yr}$ at room temperature.

Formamide Gel-Loading Buffer

Reagent

Quantity (for $10 \mathrm{~mL}$ )

Final concentration

Deionized formamide

$9.5 \mathrm{~mL}$

$95 \%$

Bromophenol blue

$2.5 \mathrm{mg}$

$0.025 \%(\mathrm{w} / \mathrm{v})$

Xylene cyanol FF

$2.5 \mathrm{mg}$

$0.025 \%(\mathrm{w} / \mathrm{v})$

EDTA (0.5 м, pH 8.0)

$100 \mu \mathrm{L}$

$5 \mathrm{~mm}$

$\mathrm{H}_{2} \mathrm{O}$

$400 \mu \mathrm{L}$

Store in aliquots at $-20^{\circ} \mathrm{C}$.

\section{Herring Testis Carrier DNA}

To make a $5 \mathrm{mg} / \mathrm{mL}$ solution, dissolve $10 \mathrm{~g}$ of herring testis carrier DNA (Type XIV) in $\mathrm{H}_{2} \mathrm{O}$ to a final volume of $2 \mathrm{~L}$. Stir until the DNA is no longer opaque, up to overnight. Autoclave the solution, aliquot in $50-\mathrm{mL}$ tubes and store for $>1 \mathrm{yr}$ at $-20^{\circ} \mathrm{C}$. Alternatively, instead of autoclaving, the carrier DNA can be sonicated and denatured. 
Prehybridization/Hybridization Mix for Northerns

\begin{tabular}{lrr} 
Reagent & Quantity (for $50 \mathrm{~mL})$ & Final concentration \\
\hline Formamide & $25 \mathrm{~mL}$ & $50 \%$ \\
SSC for northerns $(20 \times)$ & $12.5 \mathrm{~mL}$ & $5 \times$ \\
Denhardt's solution for & $1.5 \mathrm{~mL}$ & $3 \times$ \\
$\quad$ northerns $(100 \times)$ & & $200 \mu \mathrm{g} / \mathrm{mL}$ \\
Herring testis carrier & $2 \mathrm{~mL}$ & $0.1 \%$ \\
DNA & & \\
SDS $(10 \%)$ & $0.5 \mathrm{~mL}$ & \\
$\mathrm{H}_{2} \mathrm{O}$ & $8.5 \mathrm{~mL}$ &
\end{tabular}

Prepare fresh before use.

SSC for Northerns (20×)

$\underline{\text { Reagent }(20 \times) \quad \text { Quantity (for 1 L) Quantity (for } 2 \text { L) } \quad \text { Final concentration }}$

$\begin{array}{lclr}\mathrm{NaCl} & 175.3 \mathrm{~g} & 350.6 \mathrm{~g} & 3 \mathrm{M} \\ \text { Trisodium citrate } & 88.3 \mathrm{~g} & 176.5 \mathrm{~g} & 0.3 \mathrm{M} \\ \mathrm{H}_{2} \mathrm{O} & \text { to } 1 \mathrm{~L} & \text { to } 2 \mathrm{~L} & \end{array}$

Adjust the $\mathrm{pH}$ to 7.0 with $\mathrm{NaOH}$ or $\mathrm{HCl}$. Autoclave the solution and store it at room temperature. It will last for $1 \mathrm{yr}$ or longer.

TBE Electrophoresis Buffer (10X)

\begin{tabular}{lrc} 
Reagent & Quantity (for 1 L) & Final concentration \\
\hline Tris base & $121.1 \mathrm{~g}$ & $1 \mathrm{M}$ \\
Boric acid & $61.8 \mathrm{~g}$ & $1 \mathrm{M}$ \\
EDTA (disodium & $7.4 \mathrm{~g}$ & $0.02 \mathrm{M}$
\end{tabular}

salt)

Prepare with RNase-free $\mathrm{H}_{2} \mathrm{O}$. Dilute $100 \mathrm{~mL}$ to $1 \mathrm{~L}$ to make gel running buffer. Store for up to $6 \mathrm{mo}$ at room temperature.

\section{REFERENCES}

Nilsen TW. 2013. Splinted ligation method to detect small RNAs. Cold Spring Harb Protoc doi:10.1101/pdb.prot072611.

Pall GS, Hamilton AJ. 2008. Improved northern blot method for enhanced detection of small RNA. Nat Protoc 3: 1077-1084.
Rio DC, Ares M, Hannon GJ, Nilsen TW. 2010. Polyacrylamide gel electrophoresis of RNA. Cold Spring Harb Protoc doi:10.1101/pdb.prot5444. 


\section{Northern Blots for Small RNAs and MicroRNAs}

Donald C. Rio

Cold Spring Harb Protoc; doi: 10.1101/pdb.prot080838

\begin{tabular}{rc}
\hline $\begin{array}{r}\text { Email Alerting } \\
\text { Service }\end{array}$ & Receive free email alerts when new articles cite this article - click here. \\
\hline $\begin{array}{c}\text { Subject } \\
\text { Categories }\end{array}$ & $\begin{array}{c}\text { Browse articles on similar topics from Cold Spring Harbor Protocols. } \\
\text { Electrophoresis of RNA (23 articles) } \\
\text { RNA (317 articles) } \\
\text { RNA, general (269 articles) }\end{array}$ \\
\hline
\end{tabular}

